\title{
A PALAVRA E A IMAGEM: testemunhos da emblemática na assistência portuguesa da Companhia de Jesus
}

\author{
Luísa Ximenes Santos*
}

\begin{abstract}
RESUMO: analisaremos o uso da emblemática pelos jesuítas da Assistência portuguesa da Companhia de Jesus, herdeira do movimento humanista no que tange ao resgate da cultura clássica. Fundada num momento em que a Igreja Católica rediscutia o papel da imagem na difusão da fé, a Ordem jesuítica demonstrou grande preocupação não só com o discurso proferido e escrito, mas também com aquele expresso através de imagens. Diante da carência historiográfica, nos propomos a refletir sobre a produção e difusão de emblemas na Assistência portuguesa nos séculos XVI a XVIII considerando a emblemática não de um ponto de vista literário ou como simples aparato decorativo, mas como um instrumento didático, uma forma de transmitir mensagens cristãs e um tipo de discurso moralizante e político. Para tanto, nos deteremos em testemunhos do uso da emblemática pelos jesuítas em impressos, cerimônias e edificações.

PALAVRAS-CHAVE: Emblemática; Companhia de Jesus; Assistência portuguesa.
\end{abstract}

\section{The word and the image: testimonies of the emblematic one in the Portuguese Assistance of the Society of Jesus}

ABSTRACT: We will analyze the use of the emblematic by the Jesuits of the Portuguese Assistance of the Society of Jesus, heiress of the humanist movement in what concerns the rescue of the classic culture. Founded at a time when the Catholic Church was rediscussing the role of the imagery in the diffusion of faith, the Jesuit Order showed great concern not only with the uttered and written discourse, but also with that expressed throughout images. Being aware of the historiographical scarcity, we propose to bethink the production and diffusion of emblems in the Portuguese Assistance in between 16th and 18th centuries, considering the emblematic not from a literary point of view or as a simple decorative apparatus, but as a didactic instrument, a way of transmitting Christian messages and a type of moralizing and political discourse. For this, we will detain ourselves on testimonies of the use of emblematic by the Jesuits in printeds, ceremonies and buildings.

KEYWORDS: Emblematic; Society of Jesus; Portuguese assistance.

\section{La palabra y la imagen: testimonios de la emblemática en la Asistencia portuguesa de la Compañía de Jesús}

RESÚMEN: Vamos a analizar el uso de la emblemática por los jesuitas de la Asistencia portuguesa de la Compañia de Jesús, heredera del movimiento humanista en lo que se refiere al rescate de la cultura clásica. Fundada en un momento en el que la Iglesia Católica reconsideraba el papel de la imagen en la difusión de la fe, la Orden jesuita ha mostrado gran preocupación no sólo con el discurso proferido y escrito, sino también con aquel expresado a través de imágenes. Ante la carencia historiográfica, nos proponemos reflexionar sobre la producción y difusión de emblemas en la Asistencia portuguesa en los siglos XVI a XVIII teniendo en cuenta la emblemática no desde un punto de vista literario o como simple aparato decorativo, sino como una herramienta de enseñanza, una forma de transmitir mensajes cristianos y una especie de discurso moral y político. Para ello, nos detendremos en testimonios del uso de la emblemática por los jesuitas en impresos, ceremonias y edificaciones.

PALABRAS CLAVE: Emblemática; Compañía de Jesús; Asistencia portuguesa.

\footnotetext{
* Mestra em História pela Universidade Federal de Pernambuco. Atualmente é doutoranda em História junto ao Programa de Pós-Graduação da mesma Universidade. Contato: Av. da Arquitetura, s/n, Centro de Filosofia e Ciências Humanas, $10^{\circ}$ Andar, Cidade Universitária, CEP: 50740-550, Recife-PE, Brasil. E-mail: ukaxis@ hotmail.com. ORCID: http://orcid.org/0000-0002-8073-261X.
} 
A Companhia de Jesus é frequentemente caracterizada pelo seu didatismo e é lugar comum na historiografia a referência ao largo uso da imagem feito pelos jesuítas. $\mathrm{O}$ grande interesse investigativo pelo ministério catequético e missionário dessa Ordem religiosa resultou no estudo de imagens utilizadas com propósitos didáticos, como as imagens presentes nos catecismos e as de caráter mais direto, claro e de fácil entendimento que tinham por objetivo ensinar àqueles que não sabiam ler.

No presente estudo pretendemos demonstrar um outro viés: o uso bastante difundido entre os jesuítas de uma linguagem simbólica de certa complexidade para transmitir mensagens de teor vário que comunicava de maneira não tão clara, necessitando, para ser compreendida, de leituras feitas em diversos níveis: a emblemática, surgida no âmbito do movimento humanista do Quinhentos e formada por uma estreita relação entre texto e imagem cujo uso foi muito prolífero na Europa, sobretudo nos séculos XVI a XVIII.

Apesar dos testemunhos da difusão de emblemas em Portugal e em seus domínios ultramarinos e do crescente interesse pelo tema por parte de estudiosos de outros países, a historiografia portuguesa tem, de um modo geral, pouco se dedicado a essa temática. Os trabalhos tendem a restringir-se sobretudo aos campos literário e da História da Arte. $\mathrm{Na}$ historiografia brasileira a ausência de investigações sobre a emblemática é ainda mais sentida.

Diante da carência historiográfica, nos propomos a refletir sobre a produção e difusão de emblemas na Assistência portuguesa da Companhia de Jesus ${ }^{1}$ por meio de uma abordagem que considera a emblemática não de um ponto de vista literário ou como simples aparato decorativo, mas sim como um instrumento didático, como uma das formas possíveis de transmissão de mensagens cristãs e como um tipo de discurso moralizante e político.

A partir de testemunhos do uso da emblemática em obras impressas, em cerimônias e em edificações jesuíticas, tentaremos esboçar um perfil do uso de emblemas pelos jesuítas da Assistência portuguesa da Companhia de Jesus nos séculos XVI a XVIII no qual possamos vislumbrar as finalidades com que a emblemática foi utilizada.

Para além da potencialidade da imagem de fixar conteúdos, o elemento visual era usado para atrair a atenção e gerar comoção e, ainda, para instruir. Essas funções da imagem, apontadas por Gregório Magno e retomadas em ocasião do Concílio de Trento, influíram para que ela fosse adotada largamente pela Igreja no período moderno.

Antes de mais, importa definir o emblema. Composto a partir de uma estreita relação entre imagem e texto, o emblema era geralmente formado por uma estrutura tripartida. $\mathrm{O}$ lema (inscriptio) correspondia ao título do emblema; a imagem (pictura) ilustrava o conceito; e o 
epigrama (subscriptio), por sua vez, explicava a imagem. Na emblemática, assim, as expressões escrita e visual se coadunam a fim de significar e comunicar, ensinando, persuadindo e/ou moralizando.

A partir da obra tida por marco inicial da literatura emblemática, o Emblematum liber do jurista milanês Andrea Alciato (1492-1550), cuja editio princeps veio à luz em $1531^{2}$, vemos surgir na Europa, sobretudo na Bélgica, Alemanha, Itália, França e Espanha, uma enorme quantidade de livros cujos autores - médicos, poetas, cartógrafos, matemáticos, juristas, entre outros - fizeram uso de emblemas para tratar de matérias as mais variadas: ensino de príncipes, moral, ciência, política, história, medicina e tantas outras. A emblemática, portanto, não era o tema e sim o instrumento discursivo utilizado para tratar dos mais diversos assuntos.

A emblemática não deve ser pensada sem levar-se em conta a antiga interpretação alegórica e seu percurso na literatura. A alegoria, tal como foi conceituada pelos antigos gregos, ou seja, a ideia de expressar algo com um significado para além do comunicado, o manter sob véu o significado real, essa metáfora estendida - para usar as palavras de Aristóteles -, bem como a consciência da multiplicidade de conceitos e interpretações possíveis e, consequentemente, da necessidade da leitura em vários níveis estão decerto presentes na emblemática ${ }^{3}$.

Nessa linguagem simbólica percebe-se, igualmente, a reverberação do longevo uso do exemplum, das fábulas, das coleções de máximas e provérbios, dos epigramas gregos, da mitologia, bem como da crença na sabedoria divina expressa na natureza, da qual são fruto os bestiários e enciclopédias sobre plantas e minerais.

A partir dos lemas percebe-se claramente a influência de textos clássicos nos emblemas - além da Antologia Palatina, obras como as de Plutarco, Sêneca, Plínio, Horácio, Virgílio e Ovídio. As assertivas moralizantes contidas nesses textos foram transpostas, assim, em imagens.

Os emblemas, decerto, foram utilizados amplamente em variadas circunstâncias e locais. Seu uso baseou-se no poder comunicativo da imagem, na sua potencialidade de transmissão de uma mensagem, fosse ela qual fosse, visando, por exemplo, louvar personagens e feitos, memorizar, destacar virtudes, transmitir preceitos morais, ensinar a “bem viver". À função didático-moralizante estavam ligadas as funções de atração e comoção através da imagem. Imagem essa que ao atrair e comover ensina deleitando. 
O uso de imagens simbólicas foi feito desde o início no âmbito cristão devido à necessidade de representar os incorpóreos conceitos espirituais. Imagens essas que deviam estar em estreita ligação com o conteúdo da Sagrada Escritura ${ }^{4}$. Visando a uma melhor compreensão e introjeção, pelos fiéis, dos mistérios cristãos e das verdades evangélicas, a imagem simbólica foi, no mundo católico, colocada a serviço da persuasão moral e religiosa e da comunicação de realidades invisíveis.

Ainda na segunda metade do século XVI a emblemática começa a ser entendida e composta com chave de leitura cristã. Para tanto, fez-se necessária uma reelaboração dessa produção literário-artística: aplicaram-se novos significados a símbolos da emblemática profana e criaram-se elementos figurativos novos, específicos da emblemática sacra. As referências literárias nas quais se baseavam os emblemas, a princípio extraídas quase unicamente de autores clássicos - sobretudo filósofos e poetas -, passaram a referendar textos religiosos. Ao invés do uso praticamente exclusivo do latim passou-se a adotar também línguas vernáculas ${ }^{5}$.

A apropriação, adaptação e reelaboração da cultura clássica, como sabemos, não era novidade no cristianismo. Assim como os textos "pagãos" - ainda que com expurgos e modificações - foram utilizados devido a seu conteúdo ético e moralizante, incitador de bons costumes e de virtudes, a emblemática foi utilizada para veicular e difundir a fé cristã.

A Companhia de Jesus foi, dentre as ordens religiosas, aquela que mais se utilizou das potencialidades da emblemática ${ }^{6}$. Os jesuítas de fato serviram-se dela enquanto instrumento didático e para transmitir mensagens, fossem elas cristãs e/ou políticas. Eles produziram ainda tratados teóricos sobre o tema e nos colégios da Ordem a composição de emblemas era realizada como um exercício literário - sua produção emblemática foi desenvolvida nessas instituições de ensino como parte da formação humanística oferecida aos estudantes. A exercitação dos alunos na interpretação e na composição de emblemas, de fato, exigia grande conhecimento dos autores clássicos e agudeza de engenho.

No que tange à emblemática em ambiente luso, Rubem Amaral Júnior afirmou que a contribuição de Portugal no período em que esse gênero estava tendo uma ampla difusão na Europa foi "modesta, tardia, frustrada e derivada", mas que apesar disso é atestada uma significativa presença e influência de livros estrangeiros com emblemas no espaço lusitano entre os séculos XVI e XVIII.

Algumas dessas obras, vale ressaltar, receberam adaptações e traduções para o português. Amaral Júnior nos informa acerca da produção impressa de livros de emblemática 
em Portugal. A primeira dessas obras de autoria portuguesa foi publicada em Lisboa em 1596 por Manoel de Lira à custa do mercador de livros Estêvão Lopes: o Discurso sobre a Vida e Morte de Santa Isabel Rainha de Portugal, \& outras varias Rimas de Vasco Mousinho Quevedo de Castelbranco ${ }^{8}$.

Cabe ainda mencionar que em 1687 foram publicadas em Lisboa as duas primeiras partes da obra trilógica do jesuíta espanhol Francisco Garau (1640-1701) ${ }^{9}$ no idioma original das primeiras edições e, assim como elas, sem ilustrações ${ }^{10}$. Outras obras nas quais se fez uso da emblemática produzidas em Portugal permaneceram inéditas. Há ainda obras com emblemas vertidas para o português.

Se para o século XVI poderíamos apontar a ausência de uma maior preocupação quanto à arte da gravura e se no século XVII a crise econômica reverberou na imprensa portuguesa obstaculizando em parte a publicação de obras ilustradas, mais custosas, isso não pode ser afirmado em relação ao próspero reinado joanino.

Nos chama a atenção, portanto, a pequena quantidade de livros com emblemas produzidos em Portugal. A razão disso não podemos afirmar. Talvez possa ter interferido a facilidade de intercâmbio de livros com a Espanha, grande produtora de literatura emblemática; facilidade essa devida tanto à proximidade quanto ao bilinguismo característico da Península Ibérica.

A produção emblemática portuguesa, portanto, se caracteriza por uma diminuta contribuição na literatura, mas é patente nas artes aplicadas tanto no reino quanto no ultramar. Resta-nos averiguar e analisar os testemunhos do uso dessa linguagem simbólica com grande potencial para comunicar persuasivamente mensagens religiosas, moralizantes e políticas na tentativa de esboçar um perfil, ainda que lacunar, da utilização da emblemática pelos jesuítas na Assistência portuguesa.

Apesar da evidente carência de uma literatura emblemática impressa produzida pelos jesuítas da Assistência portuguesa, podem ser observados vestígios e alusões a emblemas em alguns escritos.

De uma exceção à regra nos informa Barbosa Machado, que afirmou ter saído da pena do Pe. António Vieira uma obra intitulada Emblemas moraes à Rainha D. Luiza Francisca de

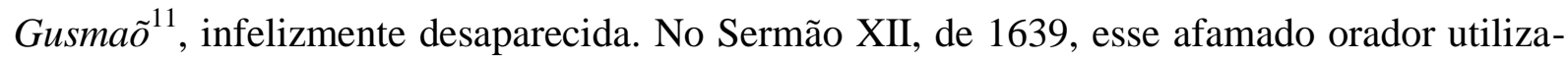
se do conceito de um emblema de Andrea Alciato para comentar a situação política do nordeste do Brasil. No final do século XVII, o mesmo Pe. Vieira escreveu uma dedicatória à rainha D. Catarina no décimo primeiro tomo de seus Sermoens adotando por fulcro duas 
empresas por ele compostas por conta do matrimônio de Catarina de Bragança com Carlos II da Inglaterra ocorrido em 1662.

Na novela alegórica História do predestinado peregrino e de seu irmão Precito, de autoria do Pe. Alexandre de Gusmão (1629-1724), impressa em Évora em 1682, também foi feita alusão a emblemas ${ }^{12}$.

Numa compilação de poesias latinas de autores jesuítas coligidas pelo Pe. Diogo da Câmara intitulada Bibliotheca latino poetica, publicada em Lisboa em 1754, por sua vez, aparecem algumas indicações "pro emblemate"13.

Nota-se ainda a presença de emblemas em frontispícios de textos impressos, ou seja, emblemas que fazem parte da representação desse elemento arquitetônico que emoldura os dados da obra e que tem por função exprimir iconograficamente o seu conteúdo.

São de se destacar os frontispícios de duas crônicas da Companhia de Jesus: o da Chronica da Companhia de Iesv na provincia de Portvgal do Pe. Baltasar Teles, cujo frontispício é igual nas partes primeira e segunda impressas em Lisboa por Paulo Craesbeeck respectivamente em $1645^{14}$ e $1647^{15}$; e o do primeiro tomo da Chronica da Companhia de Jesv do Estado do Brasil do Pe. Simão de Vasconcelos impresso em Lisboa em 1663 por Henrique Valente de Oliveira ${ }^{16}$.

No frontispício da obra do Pe. Baltasar Teles vemos a personificação alegórica da Companhia de Jesus, representada por uma mulher com o monograma "IHS" no peito olhando para a luz divina, com uma cruz com lírios indicativos da pureza na mão esquerda e escrevendo num livro com a mão direita. Abaixo lemos "Lusitana Societas IESV" e uma passagem do Salmo 103. Sobre sua cabeça sobrevoam três anjos com uma coroa cada um, representativas da doutrina, do martírio e da virgindade.

Vemos ainda muitas tarjas com inscrições, anjos que põem a coroa no escudo com as armas de Portugal, o retrato do fundador da Companhia de Jesus do lado esquerdo e, do lado direito, o do Pe. Simão Rodrigues, primeiro Provincial da província portuguesa dessa Ordem religiosa. Acima e abaixo desses retratos vemos quatro emblemas. Segurados por anjos, no plano inferior do frontispício, são figurados dois escudos com mais dois emblemas.

O emblema localizado acima do retrato de Inácio de Loyola representa uma águia olhando para o sol e, no céu, do outro lado, o monograma "IHS". Acima pode ser lido " $A b$ Ortu Solis". Do lado oposto, acima do retrato do Pe. Simão Rodrigues, vemos um outro quadro com um emblema em que estão representados novamente o sol e o monograma "IHS", desta vez acima de um edifício fortificado. 
A letra que se vê acima da figura, "Usque ad occasum", completa a que se vê acima da figura anterior, formando a frase "Ab ortu solis usque ad occasum", passagem do livro de Malaquias sobre a grandeza do nome do Senhor, que seria conhecido em todos os lugares por todas as nações, do nascente do sol ao poente. Abaixo da primeira dessas imagens pode ser lida a inscrição "Lusitana Societas in Oriente" e, na outra, "Lusitana Societas in Occidente".

Em outros dois emblemas foi dado destaque a duas terras de missões dos jesuítas. Abaixo do retrato do fundador da Companhia vemos um quadro, sob o título "Lusitana Societas in Africa". Na imagem vemos uma pessoa e um animal e lemos uma passagem do primeiro livro de Macabeus sobre a forma sábia de conciliar povos de territórios conquistados - "Consilio suo et patientia".

A imagem localizada abaixo do retrato do Pe. Simão Rodrigues, por sua vez, refere-se à "Lusit. Societas in Brasilia" e igualmente diz respeito à grande extensão das missões jesuíticas, como se depreende do lema "Unus non sufficit Orbis", retirado da décima sátira de Juvenal $^{17}$. Ao velho mundo, juntava-se o novo: na imagem vemos dois globos terrestres encimados por duas velas acesas.

$\mathrm{Na}$ parte mais baixa do frontispício, em escudos segurados por anjos que rodeiam as armas de Portugal, veem-se outros dois emblemas cujos lemas se completam, formando uma sentença da Aneida de Virgílio. De um lado, lemos "Imperium Oceano"; do outro, "Nomen qua terminat astris" ${ }^{\prime 18}$. A primeira imagem retrata um navio em alto mar; a segunda, um céu estrelado.

Os emblemas presentes no frontispício da Chronica escrita pelo Pe. Teles, portanto, representam a difusão e expansão da Companhia de Jesus não apenas no reino português, mas em todo o mundo e, consequentemente, sua obra missionária de divulgação da mensagem cristã por todo o império português.

O frontispício do primeiro tomo da Chronica da Companhia de Jesv do estado do Brasil do Pe. Simão de Vasconcelos faz alusão a esse mesmo aspecto missionário da Companhia, sendo destacado o caráter desbravador dos jesuítas da Assistência portuguesa.

O frontispício da obra é emoldurado por duas árvores nas quais se veem representadas a flora e a fauna brasileiras. Nele vemos um emblema com a mesma passagem da décima sátira de Juvenal - "Vnvs non Svfficit orbis" - que serviu de lema para um emblema do frontispício da Chronica do Pe. Teles.

A imagem é uma nau que representa a Companhia de Jesus com tripulação em alto mar, como nos é indicado pelo monograma "IHS" presente tanto na embarcação quanto numa 
de suas bandeiras. O destino, simbolizado por um globo terrestre encimado por uma onça, é o novo mundo, já que, como é alegado no lema, um só mundo não era suficiente. Não para a Companhia de Jesus, que, nas palavras do Pe. Vasconcelos, “tinha (...) já nesta puerícia de sua idade corrido quase toda a circunferência do antigo mundo"19.

Como "O bojo do Instituto da Companhia não se limita a região ou nação alguma, por mais remota, e desacomodada que pareça", os jesuítas, de acordo com o cronista, lançaram-se na conquista de um "outro mundo inteiro de almas, que havendo sido criado juntamente com as outras partes da terra, não teve a dita das demais; porque as águas imensas do oceano o dividiram do comércio dos homens, e o privaram do meio comum da fé, e salvação eterna"20.

No primeiro plano do frontispício da obra do Pe. Vasconcelos veem-se uma ampulheta, um globo, livros e instrumentos náuticos, que reforçam o espírito missionário dos jesuítas da Assistência portuguesa sobre os quais dizia-se que, tal como D. João III, desbravavam os mares e expandiam o império, tanto o territorial quanto o da fé cristã.

Nos frontispícios dessas duas crônicas, portanto, fez-se uso da emblemática não apenas para representar iconograficamente os assuntos contidos na obra, mas para exaltar as ações e expansão da Companhia de Jesus pelo mundo.

Vistos esses exemplos, passemos aos principais e mais numerosos testemunhos do uso da emblemática na Assistência portuguesa, aqueles transmitidos por relações descritivas de cerimônias públicas tais como recebimento de relíquias, exéquias, beatificação e canonização realizadas no âmbito da Companhia de Jesus, em honra de algum de seus membros ou celebrada em igreja jesuítica ${ }^{21}$.

É importante ter em mente que esses relatos não podem ser considerados parte de uma literatura emblemática. $\mathrm{Na}$ verdade, são reflexos e testemunhos escritos da existência da emblemática e aproximam-se mais dos emblemas presentes em edificações: a diferença reside no caráter de efemeridade de uns e de permanência dos outros.

Nessas relações que unem o registro escrito e a emblemática aplicada se faz referência a emblemas presentes seja em escudos carregados por figuras nas procissões, seja na arquitetura efêmera ou em ornamentos no interior da igreja; seja nas ruas, seja nos edifícios. Nenhuma dessas relações, contudo, é ilustrada ${ }^{22}$.

A primeira dessas relações em que encontramos referência a emblemas, a Relaçam do solenne recebimento que se fez em Lisboa ás santas reliquias $q^{\sim}$. se leuáram à igreja de $S$. Roque da companhia de IESV aos. 25. de Ianeiro de 1588 escrita por Manoel de Campos, foi impressa em Lisboa por Antonio Ribeiro nesse mesmo ano de $1588^{23}$, antecedendo em alguns 
anos, portanto, a impressão da obra de Vasco Mousinho Quevedo de Castelbranco ${ }^{24}$, pioneira no gênero da literatura emblemática em Portugal.

A mais tardia das relações nas quais nos deteremos, por sua vez, data de 1755 - uma descrição das exéquias de D. Maria Ana de Áustria celebradas pelos Padres Procuradores das missões do Oriente na Igreja do Colégio de Santo Antão em $1754^{25}$, ou seja, poucos anos antes da expulsão da Companhia de Jesus.

No Seiscentos há provas da presença de emblemas em celebração da beatificação do Pe. Francisco Xavier ${ }^{26}$, da sua canonização juntamente com a de Inácio de Loyola $^{27}$ e das exéquias do Pe. António Vieira, apesar de a relação desta última ter sido impressa apenas em $1730^{28}$.

É no século XVIII que se concentra a maioria dos testemunhos do uso de emblemas na Assistência portuguesa, provavelmente devido tanto à prosperidade do reinado joanino e o investimento na suntuosidade e demonstração do poder, reverberado na realização de festas, quanto a um maior desenvolvimento tipográfico. Nos deparamos com emblemas em festa de beatificação do jesuíta francês João Francisco Régis ${ }^{29}$, de canonizações dos jesuítas Luiz Gonzaga e Estanislau Kostka ${ }^{30}$ - o primeiro italiano; o outro, polaco - e de exéquias do $5^{\circ}$ Conde da Ericeira e $1^{\circ}$ Marquês do Louriçal Luís Carlos Inácio Xavier de Meneses (1689$1742)^{31}$.

Os principais motivos apontados como razão de ser dessas relações de cerimônias foram sua perpetuação na memória, estimular a devoção, divulgar as glórias de Deus, da Companhia de Jesus, de Portugal e/ou daquele que estava sendo homenageado, cujas virtudes eram sempre louvadas.

Os leitores aos quais se dirigiam essas relações eram tanto aqueles que foram à cerimônia, quanto os que não a presenciaram. A relação escrita servia de instrumento para explicar e comentar certos elementos da festa, como os emblemas. Ademais, nas relações registravam-se muitos elementos que podiam passar despercebidos ou que não puderam ser vistos completamente nem mesmo por aqueles que presenciaram a cerimônia.

Mas quem era esse público que pôde ver com os próprios olhos e participar dessas festas descritas sempre como singulares? Essas festividades, regra geral, nas quais para além dos padres e estudantes da Companhia de Jesus envolviam-se membros de outras comunidades religiosas, contavam com um público vário e participativo, tanto da cidade que festejava quanto de outras partes. Essas cerimônias eram grandes eventos e para tanto havia 
uma especial preparação tanto das pessoas, quanto da cidade em si. Delas participava grande multidão de "povo" e também muitas pessoas da nobreza.

Vemos nessas festas um entrelaçamento entre o Estado e a Igreja. Do mesmo modo que pessoas investidas de altos cargos políticos e mesmo a família real participavam das celebrações em honra de algum membro da Companhia de Jesus, os jesuítas prestaram homenagens a esses homens de Estado.

A teatralidade e simbólica do poder presente em todas essas ocasiões festivas era feita em parte através da ostentação. A transmissão da ideia de uma monarquia próspera e o incitamento de reverência à Igreja eram feitos através da suntuosidade, manifesta na formalidade dessas cerimônias que movimentavam a cidade, nas pessoas que delas participavam, no repique dos sinos, na enorme quantidade de luminárias, na música da Capela Real, nos aparatosos fogos de artifício, nas peças emprestadas do tesouro real, na maravilha e riqueza dos tecidos, nas figuras de procissão montadas a cavalo, nas pedras preciosas e nos aparatos construídos especialmente para a ocasião, nos quais figuraram emblemas.

Essas celebrações certamente eram impregnadas de simbolismo, verificável por exemplo nos carros triufantes, na armação da igreja e nas figuras processionais que eram no mais das vezes personificações alegóricas com roupas de determinadas cores e enfeites, com atributos, escudos e trunfas.

A existência de emblemas nas festas algumas vezes foi aludida nas relações sem quantificá-los, mas essas referências feitas de forma evasiva não foram a regra, mas a exceção. Os emblemas figuraram em arcos, medalhas, faixas, tarjas, pilares e colunas nas igrejas, em claustros, em carros triunfantes e em escudos levados por estátuas ou por figuras na procissão pelas ruas da cidade. Foram, portanto, vistos por um público vário, composto por pessoas com diferentes graus de instrução. Em consequência disso, igualmente heterogênea era a apreensão da mensagem transmitida e a atração causada pelos emblemas.

As pessoas eram atraídas pela força impressiva e expressiva do elemento visual tanto nas procissões quanto nas visitas à igreja nessas solenidades em que se desfilava e exibia o fausto da Igreja e da monarquia. Essas festas eram espetáculos que davam "deliciosa vista aos olhos" 32 .

Além disso, os elementos visuais estimulavam a devoção. Alguns espectadores acresciam à simples atração visual o prazer em reconhecer ou decifrar os simbolismos que passavam diante de seus olhos. Nessas festas, portanto, as pessoas "recreauam os olhos, \& alegrauam o entendimento"33. Era possível ainda ler as relações em que se descreviam esses 
elementos, inclusive os emblemas. Nas relações das quais nos ocupamos, apesar de não serem ilustradas, eles foram descritos, explicados e às vezes até comentados.

Na relação do solene recebimento de relíquias de 1588 os emblemas foram descritos e a alguns - não a todos - foi dada uma explicação simples:

O emblema do silencio era este. Outro Anjo com hũa clepsidra, q mostraua estar chea dagoa na mão, sem se ir, porque lhe tinha tapada a boca cõ o dedo, o que declaraua esta letra.

Inter punctá patet, rimisq'; incisa fatiscit:

Os claudo, \& refugas clepsydra sistit aquas.

Este vaso cõ estar todo picado, \& aberto,

tapãdolhe a boca não se lhe vay a agoa.

Declarãdo alegoricamente como cõ a guarda da boca se cõserua o dom da pureza. ${ }^{34}$

Na relação da cerimônia de exéquias do Pe. António Vieira ocorrida em Lisboa trinta e duas empresas foram descritas de maneira sucinta, como por exemplo: "Hum casullo de seda, de que sahe huma borboleta: Praetium post funera",35.

Nos vários relatos das festas realizadas por conta das canonizações dos padres Luiz Gonzaga e Estanislau Kostka os emblemas aparecem ora apenas descritos, ora também explicados e em alguns casos até comentados, o que aconteceu igualmente na descrição da cerimônia de exéquias de D. Maria Ana de Áustria celebrada pelos padres provinciais das missões orientais em Lisboa em 1754:

Nas duas faixas (...) se viaõ outros tantos testemunhos das Reaes acções da Magestade defunta nos Emblemas. Tinha o primeiro por figura huma tocha acesa, a qual, por allumiar a todos, e só se consumir a si, era symbolo do soffrimento, com que a Raînha Fidelissima a ninguem era molesta; antes imputava á sua innocencia os erros alheyos. Isto mesmo se declarava neste titulo, que ao mesmo tempo, que era explicaçaõ da figura, tambem era elogîo do Assumpto.

Ut nemini esset gravis, aliorum crimina sibi saepissimè ducebat.

A tudo dava a ultima luz este verdadeiro lemma:

Tantùm in me saeva, $\&$ noxia nulli. ${ }^{36}$

Não é possível delimitar um tipo único de emblema presente nessas cerimônias. Devemos nos perguntar, por exemplo, se uma figura, personificação alegórica de algo, ao desfilar em procissão carregando determinados objetos e escudo com uma frase configuraria um "emblema vivo". A figura que representava a Melodia no sétimo aplauso da procissão feita em Lisboa em ocasião das canonizações de Luiz Gonzaga e Estanislau Kostka, por exemplo, "leuaua no peito hum cirne, \& nas maõs hũs orgaõs dourados, com esta letra: In aure melos" de São Bernardo de Claraval (1090-1153) ${ }^{37}$. 
Feitas essas ressalvas, passemos então a uma análise mais geral. O lema esteve quase sempre presente, com raras exceções. Praticamente todos os lemas foram escritos em latim. Exceções foram um lema em grego e outro em hebraico, ambos presentes num carro sobre a honra humana da celebração em Coimbra das canonizações do fundador da Companhia de Jesus e de Francisco Xavier em $1622^{38}$. Ademais, o Conde da Ericeira compôs quatro emblemas em homenagem ao Pe. António Vieira na celebração de suas exéquias, em diferentes línguas faladas pelo jesuíta: latim, espanhol, italiano e português ${ }^{39}$.

As fontes dos lemas, entretanto, na maior parte das vezes não foram explicitadas. $\mathrm{Na}$ relação do recebimento das relíquias em São Roque em 1588 temos notícia de um cuja fonte é Agostinho de Hippona e outros emblemas têm passagens bíblicas por lema.

Alguns emblemas presentes na celebração, em Lisboa, das canonizações de Inácio de Loyola e de Francisco Xavier também foram compostos com lemas extraídos da Sagrada Escritura, mas num carro triunfal pertencente ao primeiro aplauso há um emblema cujo lema é uma sentença de Plínio e outro cuja letra é um dito de Horácio ${ }^{40}$. Na cerimônia realizada em Braga os exemplos em que se explicita a fonte dos lemas são todos bíblicos, à exceção de um de Virgílio, denominado por antonomásia na relação como o "Poeta"41.

Tanto na descrição da celebração, em Évora, pela beatificação do Pe. João Francisco Régis em 1716, quanto nos relatos das festas realizadas pelos jesuítas da Casa Professa de São Roque e pelos do Colégio de Évora aquando das canonizações de Luiz Gonzaga e Estanislau Kostka em 1728 as fontes explicitadas são sobretudo bíblicas. Já na cerimônia de exéquias de D. Maria Ana de Áustria realizada pelos Padres Procuradores das missões do Oriente há referência apenas a uma fonte - um "dito do Poéta"

A partir das fontes dos lemas que foram explicitadas nas relações, portanto, sabemos que elas foram tanto bíblicas quanto de autores clássicos. Para além desses lemas, é importante ressaltar que em alguns casos determinou-se ainda um "título" para o emblema ${ }^{43}$.

Os epigramas, ao contrário dos lemas, não eram frequentes. Pelo menos não nas relações descritivas. São exemplos os pertencentes aos quatro emblemas compostos pelo Conde de Ericeira em homenagem ao Pe. António Vieira em ocasião de sua morte ${ }^{44}$ e alguns epigramas em espanhol de empresas presentes nas festas de canonização de Inácio de Loyola e Francisco Xavier em Braga, caso daquelas que podiam ser vistas em painéis dos lados de um carro: "era hum Lobo junto a hum Cordeiro, tinha por letra: Habitabit lupus cum agno. Declaraua a tençaõ este terceto. Del lobo, que al corderillo / Natura hizo contrario, / Hizo el Agnus relicario" 45 . 
Os elementos que compunham as imagens dos emblemas eram objetos, partes do corpo humano, fenômenos da natureza, corpos celestes, água, fogo, elementos geográficos, labirintos, edifícios, personagens bíblicos ou mitológicos, minerais, vegetais e animais.

O principal intuito das celebrações de beatificações, canonizações e exéquias de que nos ocupamos foi sem dúvida pôr em relevo virtudes com o propósito seja de exaltar o cristianismo, a Igreja Católica ou a Companhia de Jesus em seus membros, seja de louvar a monarquia portuguesa, fixando suas qualidades na memória dos súditos, que eram incitados a sentir grande pesar quando um "sol" como D. João V ou como sua esposa D. Maria Ana de Áustria eram "eclipsados".

As virtudes desfilavam pelas ruas personificadas alegoricamente, eram ressaltadas nos sermões, eram vislumbradas nos emblemas. A exaltação de qualidades e ações virtuosas sem dúvida servia para louvar os novos beatos e santos como homens singulares merecedores de grande admiração e que deveriam servir de exemplo para os demais. No caso das cerimônias de exéquias, diferentemente, esse louvor servia ainda para incitar o respeito e para aumentar o pesar e a saudade causados pela morte de pessoa tão virtuosa, como, por exemplo, se depreende das seguintes passagens do relato das festas em homenagem à D. Maria Ana de Áustria:

\footnotetext{
Por todos os lados encontravã̃ os olhos Emblêmas, Epitaphios, e Elogîos Sepulcráes, que faziaõ a perda da Fidelissima Raînha tanto mais sentida, quanto mais lembrada.

(...)

Os lados destas duas Capellas ajudáraõ a explicar o sentimento, que respirava todo o Templo; porque o seu funebre ornato animou nesta occasiaõ os mesmos mármores: e fazendo a dor dos vivos éco nas mesmas pedras, eraõ estas com o seu triste ornato hum retrato dos nossos corações, e com os Emblemas hum clamor da nossa saudade, pelo que perdemos. ${ }^{46}$
}

Nessas cerimônias suntuosas criava-se uma atmosfera e um ambiente alegre ou lúgubre propício ao louvor de homens exemplares - jesuítas ou não, mas todos devotos e virtuosos. Tudo convergia para esse fim: a grande multidão de "povo" e as pessoas ilustres da cidade e de outras regiões, a riqueza das vestimentas, as luminárias, os fogos, a armação da igreja e das ruas para a procissão, os aparatos festivos e os emblemas.

Estes últimos elementos, nas diversas cerimônias ocorridas no reino e domínios ultramarinos portugueses relacionadas com a Companhia de Jesus, portanto, para além de agradarem os olhos e entreterem o entendimento foram um instrumento para destacar virtudes, para incitar os ânimos ao louvor e à reverência. Serviram para propagar os preceitos cristãos, moralizando o público e incitando-o a seguir o exemplo de homens virtuosos. 
Ademais, tais emblemas foram um elemento de discurso político, assim como os sermões proferidos: exaltava-se a monarquia portuguesa e aproveitava-se para enfatizar a boa relação estabelecida entre ela e os jesuítas; louvavam-se os novos beatos e santos, o que igualmente reverberava na propaganda e louvor à própria Companhia de Jesus.

Por fim, cabe-nos referir o uso da emblemática em igrejas jesuíticas. Símbolos alusivos à Maria figuram no teto setecentista da sacristia da Igreja da Casa-Colégio da Madre de Deus em Vigia, no Grão-Pará, dividido em quatro caixotões. As quatro imagens possuem lemas, o que as configura como emblemas marianos. São eles: "Stella Maris", "Electa vt Sol”, "Stella Matvtina" e "Pvlchra vt Lvna"47.

É de se destacar o caso de outros quatro emblemas presentes igualmente no forro da sacristia de um templo jesuítico paraense: o da Igreja de São Francisco Xavier do Colégio de Santo Alexandre em Belém, pintado no século XVIII ${ }^{48}$.

No centro do teto, repleto de elementos fitomórficos, vemos pintada uma cartela ladeada e sustentada por dois anjos, que também seguram uma coroa. Na cartela vemos uma cruz e três cravos, entre o que, de acordo com Renata Martins, haveria o monograma "IHS"49. Em cada um dos quatro cantos do forro vemos um emblema.

No primeiro deles, sob uma faixa vermelha onde se lê "Nomen Terribile" e com o lema "[F]vgat vt fvlget" - Afugenta ao brilhar - vemos um sol ardente e alguns pássaros sobrevoando um campo destruído e infértil.

Possivelmente esse emblema sobre o temível nome de Deus é baseado no capítulo 28 do Deuteronômio, no qual o homem é alertado, para além das bençãos advindas da obediência, sobre as maldições que sofreria se não observasse "todas as palavras desta lei, consignada neste livro, em sinal de reverência pelo nome glorioso e temível de Javé, teu Deus" (Dt. 28, 58).

Podemos vislumbrar na imagem correspondências com o texto bíblico: "será maldito (...) o fruto do teu solo" (Dt. 28, 8), "o céu que está por cima da tua cabeça será de bronze" (Dt. 28, 23), “Teu cadáver servirá de pasto a todas as aves do céu” (Dt. 28, 26), “Andarás às apalpadelas em pleno meio-dia como o cego na escuridão" (Dt. 28, 29), "Os frutos de tua terra e de teu trabalho serão comidos por um povo que não conheces" (Dt. 28, 33), "Lançarás sementes em abundância nos teus campos, mas colherás pouco, porque o gafanhoto devastará tudo. Plantarás a vinha, e dela cuidarás, mas não beberás vinho, nem nada colherás, porque o verme devorará tudo" (Dt. 28, 38. 39). 
Ademais, "O Senhor suscitará contra ti das extremidades da terra uma nação longínqua, rápida como a águia" (Dt. 28, 49) que "devorará o fruto de teus rebanhos e os produtos de teu solo, até que sejas aniquilado, e nada te deixará, nem trigo, nem vinho, nem óleo, nem a cria de tuas vacas, nem os filhotes de tuas ovelhas, até a tua ruína” (Dt. 28, 51).

No segundo emblema presente na sacristia de Belém vemos uma mão saída de uma nuvem segurando uma jarra com a qual verte óleo num vale. O lema é "Lux cibus et medicina" e numa faixa próxima se lê "Nomen Admirabile".

A fonte do emblema é o sermão XV dos Sermones super Cantica Canticorum de São Bernardo de Claraval, em que ele associa ao nome do Senhor as propriedades do óleo de iluminar, nutrir e ungir: Ele seria luz para a mente, alimento para o coração e remédio para a alma.

No terceiro emblema, com o lema "Rejicit avt frangit", uma nuvem segurando um escudo que quebra as flechas que o atingem. Numa tarja próxima lemos "Nomen Invincibile".

A origem desse emblema pode ser buscada em várias passagens da Sagrada Escritura. A proteção de Deus, o "rei invencível que permanece para sempre” (Eclesiástico 18, 1), foi muitas vezes evocada através do significado do escudo e as flechas simbolizam os perigos e os inimigos. Lemos passagens que afirmam que "O meu escudo é Deus" (S1. 7, 11), "escudo para os que caminham com integridade" (Pv. 2. 7).

No capítulo 22 do segundo Livro de Samuel, Ele é descrito como "meu escudo e força de minha salvação, minha cidadela e meu refúgio. Meu salvador, que me salvais da violência" (II Sm. 22, 3), “o escudo de todos os que nele se refugiam” (II Sm. 22, 31) e, além disso, dizse que Ele dá ao homem o escudo que o salva (II Sm. 22, 36).

Ademais, "Sua fidelidade te será um escudo de proteção. Tu não temerás os terrores noturnos, nem a flecha que voa à luz do dia" (S1. 90, 4. 5). Toda a Sua palavra "é provada, é um escudo para quem se fia nele" (Pv. 30. 5). Se deve embraçar ainda "o escudo da fé, com que possais apagar todos os dardos inflamados do Maligno" (Ef. 6, 16).

$\mathrm{Na}$ faixa que encima o quarto e último emblema da sacristia da Igreja de São Francisco Xavier lemos “Nomen Delectabile”. Sob o lema "Sonvm dvlcedo seqvetur" - Que a doçura siga o som - vemos uma mão saindo de uma nuvem tocando uma sineta e abelhas próximas a um cortiço, local onde elas produzem o mel.

Os dois elementos contidos no lema - o som e a doçura - encontram-se representados nesse emblema: a sineta e a abelha. Esse animal tido por virtuoso nos bestiários medievais e 
que, no Physiologus, é associado a Cristo, que teria dado o mel aos homens e, depois, se sacrificado por eles ${ }^{51}$, foi associado à doçura em mais de uma passagem da Sagrada Escritura. Lemos, por exemplo, no Eclesiástico $(11,3)$ : "Pequena é a abelha entre os seres alados: o que produz, entretanto, é o que há de mais doce”. Ademais, diz-se que “As palavras agradáveis são como um favo de mel; doçura para a alma e saúde para os ossos" (Pv. 16, 24).

Acreditamos que uma interpretação possível é a de que esse emblema seja referente ao ministério da pregação. Pregação essa que deveria ser feita visando o proveito e o deleite dos ouvintes, os quais deveriam seguir esse harmônico "som" sobre as doces palavras de Jesus e congregar-se na Igreja.

\section{Conclusão}

Concluímos, com o estudo por nós desenvolvido, que a produção emblemática dos jesuítas da Assistência portuguesa nos séculos XVI a XVIII foi coerente com o restante da produção emblemática em Portugal: se não teve destaque nos livros impressos, esteve abundantemente presente nas celebrações e figurou ainda em edificações.

Os jesuítas da Assistência portuguesa, bastante convictos da utilidade do elemento imagético e influenciados pelo humanismo no que tange ao estudo dos clássicos, serviram-se da emblemática como instrumento para comunicar a um público vário: para transmitir-lhe a mensagem cristã, para moralizá-lo e para propagar discursos políticos de defesa e louvor da monarquia e da própria Companhia de Jesus.

Como vimos, esse uso da emblemática pelos jesuítas foi feito desde os primeiros anos após a fundação da Companhia. Eles se utilizaram dessa linguagem escrita e visual no conturbado período de reforma em que a Igreja Católica defendeu a utilidade das imagens perante o iconoclasmo protestante; dela fizeram uso também no século XVII, mesmo em meio às críticas feitas pelos jansenistas à Companhia de Jesus, aí inclusa a censura ao demasiado uso do símbolo feito pelos membros dessa Ordem; e continuaram a utilizá-la no século XVIII.

Como depreendemos das relações descritivas de cerimônias e dos testemunhos supérstites de emblemas nas sacristias paraenses, a emblemática foi largamente utilizada pelos jesuítas da Assistência portuguesa até as vésperas de sua expulsão, em 1759. Esses membros da Companhia de Jesus, portanto, serviram-se dessa linguagem simbólica no século normalmente apontado como o da "morte" da emblemática e do declínio do simbolismo de modo geral. Mas também século de prosperidade para o Portugal joanino, século de 
desenvolvimento tipográfico, de grande circulação de artistas e de livros e de realização de suntuosas festas no reino e nos domínios ultramarinos portugueses.

\title{
Notas
}

\begin{abstract}
${ }^{1}$ Assistência é uma divisão administrativa da Companhia de Jesus formada por um grupo de províncias ligadas geográfica e linguisticamente. É administrada por um Assistente eleito pelo Superior Geral e escolhido através de uma Congregação Geral: o representante em Roma de sua Assistência e consultor do Padre Geral nos negócios a ela relativos. Eram seis as Assistências da Companhia: Itália, Portugal, Espanha, Alemanha, França e Polônia. Por província jesuítica entende-se a unidade territorial administrativa da qual se encarregava um Superior provincial nomeado pelo Superior Geral da Companhia de Jesus. Além da questão geográficolinguística, uma província jesuítica deveria, para ser formada, ter recursos suficientes para garantir sua existência no que tange ao sustento e ao recrutamento. A província portuguesa da Companhia de Jesus, ereta oficialmente por Inácio de Loyola em decreto de 25 de outubro de 1546 e que teve por primeiro Provincial o Pe. Simão Rodrigues, criada a partir do modelo administrativo das ordens mendicantes, foi a primeira dessas unidades administrativas autônomas a ser instituída. A Assistência de Portugal compreendia o reino e as ilhas adjacentes, as possessões lusas na África, todo o Brasil, a China, a Indo-China, a Índia, o Tibet, as Molucas e o Japão. Vd. LEITE, Serafim. História da Companhia de Jesus no Brasil, 10 vols. Porto, Rio de Janeiro: Tipografia Pôrto Médico, Imprensa Nacional, 1938-1950, (t. I, p. 12); GIARD, Luce. Le devoir d'intelligence ou l'insertion des jésuites dans le monde du savoir. In: (dir.). Les jésuites a la Renaissance. Système éducatif et
\end{abstract} production du savoir. Paris: Presses Universitaires de France, 1995, p. XI-LXXIX (p. XIII); RODRIGUES, Francisco. História da Companhia de Jesus na Assistência de Portugal, 7 vols. Pôrto: Apostolado da Imprensa, 1931-1950, (t. I, vol. I, p. VIII (nota 1)).

${ }^{2}$ Augsburg: Heinrich Steyner, 1531.

${ }^{3}$ A discussão acerca da tradição alegórica literária foge ao escopo deste trabalho e portanto remetemos para os seguintes estudos que dão uma visão geral da questão: RAYBOULD, Robin. An introduction to the symbolic literature of the renaissance. Victoria: Trafford Publishing, 2005, (p. 191-208); MURRIN, Michael. Renaissance allegory from Petrarch to Spencer. In: COPELAND, Rita; STRUCK, Peter T. (eds.). The Cambridge Companion to allegory. Cambridge: Cambridge University Press, 2010, p. 185-200.

${ }^{4} \mathrm{Vd}$. INSOLERA, Lydia Salviucci. L'Imago Primi Saeculi (1640) e il significato dell'immagine allegorica nella Compagnia di Gesù. Genesi e fortuna del libro. Roma: Editrice Pontificia Università Gregoriana, 2004, p. 11-3.

${ }^{5}$ MANNING, Patricia W. La emblemática jesuítica en El Criticón. eHumanista, vol. 9, p. 218-40, 2007 (p. 220).

${ }^{6}$ A produção de livros com emblemas no âmbito da Companhia de Jesus foi bastante significativa, tendo sido os jesuítas, de acordo com as estimativas, responsáveis por cerca de um terço do número total de obras consideradas pertencentes ao gênero da emblemática produzidas durante a Idade Moderna. Essas estimativas são caracterizadas por uma classificação fluida do que se entende por "livro de emblema" e nelas incluem-se as múltiplas edições de cada obra, bem como as traduções das mesmas. No The Jesuit Series (Corpus Librorum Emblematum) foi apontada a existência de 501 obras jesuíticas de emblemática. Importa ressaltar que os números totais relativos às obras de emblemática e os relativos àquelas de autoria jesuítica não são fixos, sendo modificados constantemente devido às descobertas investigativas. Vd. DIMLER, G. Richard; DALY, Peter Maurice (eds.). The Jesuit Series (Corpus Librorum Emblematum). Toronto, Buffalo: University of Toronto Press, 1997-2007, 5 vols.

${ }^{7}$ AMARAL JÚNIOR, Rubem. Portuguese Emblematics: an overview. Revista Lumen et Virtus, v. 2, n. 4, p. 134-48, mai. 2011, (p. 135).

${ }^{8}$ CASTELBRANCO, Vasco Mousinho Quevedo de. Discrrso sobre a vida, e morte, de Santa Isabel Rainha de Portugal, \& outras varias Rimas. Por Vasco Mousinho de Castelbranco. Dirigido ao Excellentissimo Senhor Duque, Dom Aluaro de Lancastre. Lisboa: Por Manoel de Lyra, à custa de Esteuão López mercador de liuros, 1596.

${ }^{9}$ Lisboa: en la imprenta de Theotonio Craesbeeck de Mello, Impressor de su Magestad, a su costa impresso, y de Antonio Leyte Pereira mercader de livros, 1687.

${ }^{10}$ GARAU, Francisco. El sabio instruido de la naturaleza en quarenta maximas politicas, y morales, illustradas con todo genero de erudicion sacra, y humana. Barcelona: Em Casa Cormellas, por Vicente Suria, 
à custa de Antonio Ferrer, 1675;

El Olimpo del sabio instruido de la naturaleza y segunda parte de las maximas politicas, y morales, ilustradas con todo genero de erudicion sacra y humana. Barcelona: Antonio e Baltasar Ferrer, 1680. Completa a obra trilógica a seguinte parte: Tercera parte del sabio instruido de la naturaleza con esfuerzos de la verdad... alegados en quarenta y dos máximas políticas y Morales ilustradas con todo genero de erudición... contra las vanas ideas de la Politica de Machiavelo. Barcelona: Imprenta de Cormellas, por Tomás Loriente, 1700.

${ }^{11}$ MACHADO, Diogo Barbosa. Bibliotheca Lusitana, Historica, Critica, e Chronologica, na qual se comprehende a noticia dos Authores Portuguezes, e das Obras, que compozeraõ desde o tempo da promulgaçaõ da Ley da Graça até o tempo presente; por Diogo Barbosa Machado, Ulyssiponense, Abbade Reservatario da Paroquial Igreja de Santo Adrião de Sever, e Academico do Numero da Academia Real. Lisboa: Na Officina Patriarcal de Francisco Luiz Ameno, 1759, (t. I, p. 425).

${ }^{12}$ Vd. MASSIMI, Marina (org.). A novela História do predestinado peregrino e de seu irmão Precito (1682). Compêndio dos saberes antropológicos e psicológicos dos jesuítas no Brasil colonial. São Paulo: Edições Loyola, 2012, (p. 85, 93).

${ }^{13}$ BIBLIOTHECA latino poetica, varia complectens opuscula latinorum poetarum e societate jesu qui in lusitana Peovincia florent... Nunc primùm collecta, digestaque opera ac studio P. M. Didaci Camarae, 2 vols. Ulyssipone: ex pracio Michaelis Manescal da Costa, 1754, (p. 292-4).

${ }^{14}$ TELES, Baltasar. Chronica da Companhia de Iesv, na provincia de Portugal; e do qve fizeram, nas conquistas d'este Reyno, os Religiosos, que na mesma Provincia entràram, nos annos em que viveo $\mathrm{S}$. Ignacio de Loyola, nosso Fundador. Pelo P. M. Balthazar Tellez da mesma Companhia, natural da cidade de Lisboa, \& nella Lente de Prima de Theologia. Primeira parte, na qval se contem os principios d'esta Provincia, No tempo, em que a fundou, \& governou o P. M. Simam Rodrigves, Com sua sancta vida, \& morte. Lisboa: por Paulo Craesbeeck, 1645. Disponível em: <https://digital.bbm.usp.br/handle/bbm/4678>. Acesso em: 24/07/2018, 16:09:38.

${ }^{15}$ TELES, Baltasar. Chronica da Companhia de Iesv, da provincia de Portugal. Segvnda parte, na qual se contem as vidas de algũs Religiosos mais assinalados, que na mesma Provincia entràram, nos annos em que viveo S. Ignacio de Loyola, nosso fvndador. Com o svmmario das vidas dos Serenissimos Reys Dom Ioàm Terceyro, \& Dom Henrique, Fundadores, \& insignes bemfeytores desta Provincia. Composta pelo P. M. Balthezar Telles, da mesma Companhia, natural da Cidade de Lisboa. Lisboa: por Paulo Craesbeeck, 1647. Disponível em: <https://digital.bbm.usp.br/handle/bbm/4690>. Acesso em: 24/07/2018, 16:11:05.

${ }^{16}$ VASCONCELOS, Simão de. Chronica da Companhia de Jesv do estado do Brasil: e do qve obrarão sevs filhos nesta parte do Novo mvndo. Tomo primeiro: da entrada da Companhia de Jesv nas partes do Brasil. E dos fvndamentos qve nellas lançârão, \& continuàrão seus religiosos em quanto alli trabalhou o padre Manoel da Nobrega, fundador, \& primeiro prouincial desta prouincia, com sua vida, \& morte digna de memoria: e alg ṽas Noticias antecedentes curiosas, \& necessarias das cousas daquelle estado. Lisboa: H. Valente de Oliuiera, impressor del Rey, N. S., 1663.

${ }^{17}$ Disponível em: http://www.thelatinlibrary.com/juvenal/10.shtml. Acesso em 09/12/2018.

${ }^{18}$ Livro I, v. 286. Na verdade, esse verso é assim escrito: "Imperium Oceano, famam qui terminet astris".

${ }^{19}$ VASCONCELOS, Simão de. Crônica da Companhia de Jesus. Petrópolis, Brasília: Vozes, Instituto Nacional do Livro, 1977, 2 v., (v. I, Livro Primeiro da Crônica da Companhia de Jesus do Estado do Brasil, §1, p. 169).

${ }^{20}$ Idem, §2, p. 170.

${ }^{21}$ Para além dessas relações, importa ressaltar que o Pe. Teles, no primeiro volume de sua Chronica, relata que numa cerimônia de recebimento de relíquias ocorrida no Colégio de Coimbra em 1544, festejou-se, dentre outras formas, com poemas e emblemas (Vd. TELES, Baltasar. Chronica da Companhia de Iesv, na provincia de Portugal... op. cit., Livro Primeiro, Capítulo XXXXI, §3, tópico "Sam festejadas no Collegio de Coimbra as onze mil virgens", (p. 206)). Temos notícia ainda de que um arco triunfal com cerca de vinte emblemas foi realizado em 1680 pelo jesuíta João Felipe Bettendorff (1625-1698) e erguido em São Luís, em frente à igreja de Nossa Senhora da Luz, para a chegada do primeiro Bispo do Maranhão (BETTENDORFF, João Felipe. Crônica dos Padres da Companhia de Jesus no Estado do Maranhão. Belém: Fundação Cultural do Pará Tancredo Neves; Secretaria do Estado da Cultura do Pará, 1990, (p. 328-9) apud MARTINS, Renata Maria de Almeida. Un emblema volante...! A adaptação da tradição emblemática nas missões jesuíticas da América Latina (séculos XVI-XVIII). In: CHAMBOULEYRON, Rafael; ARENZ, Karl-Heinz (orgs.). Anais do IV Encontro Internacional de História Colonial. Encontros com a história colonial. Belém: Editora Açaí, 2014, v. 1, p. 236-51, (p. 244)). Ademais, temos conhecimento de um certame poético que constou de cem emblemas no segundo ato das quarenta sessões literárias organizadas pelo Pe. Manoel de Azevedo em ocasião do segundo centenário da Companhia de Jesus - um banquete simbólico ocorrido no dia 10 de julho de 1741. Merece ainda ser referido que na Relação sumaria dos funebres obsequios feitos em Salvador em honra de Manoel de Mattos Botelho em 1744 são apontados três emblemas assinados pelo colégio jesuítico da Bahia (Vd. BIBLIOTECA 
NACIONAL. Anais da Biblioteca Nacional, v. 83, 1963. Brasiliana da Coleção Barbosa Machado. Catálogo organizado pela bibliotecária Rosemarie Horch. Divisão de Publicações e Divulgação, 1967, n. 107, p. 136-43 (p. 142)).

${ }^{22}$ As poucas imagens contidas em algumas das relações são apenas letras capitulares, gravuras que figuram em páginas de rosto ou que separam as partes da obra. Não são, portanto, ilustrações de elementos presentes nas cerimônias descritas.

${ }^{23}$ CAMPOS, Manoel de. Relaçam do solenne recebimento que se fez em Lisboa ás santas reliquias q ${ }^{\sim}$. se leuáram à igreja de S. Roque da companhia de IESV aos. 25. de Ianeiro de 1588. Pello Licenciado Manoel de Campos. Lisboa: per Antonio Ribeiro, 1588. Os emblemas presentes na cerimônia descritos nessa Relaçam foram alvo de investigação de Amaral Júnior no seguinte artigo: AMARAL JÚNIOR, Rubem. Programa emblemático do recebimento das santas relíquias na igreja de S. Roque, em Lisboa (1588). In: CHAPARRO, César; GARCÍA, José Julio; ROSO, José; UREÑA, Jesús (eds.). Paisajes emblemáticos: la construcción de la imagen simbólica en Europa y América. Actas del V Congreso Internacional de la Sociedad Española de Emblemática, 2 v. Mérida: Editora Regional de Extremadura, 2008, v. 1, (p. 317-39).

${ }^{24}$ CASTELBRANCO, Vasco Mousinho Quevedo de. Discvrso sobre a vida, e morte, de Santa Isabel Rainha de Portugal... op. cit.

${ }^{25}$ DESCRIPÇAÕ das exequias, que a' fidelissima rainha de Portugal a senhora D. Maria Anna de Austria, De feliz, e saúdoza Memoria, celebraraõ os PP. Procuradores Das Missoẽs do Oriente da Companhia de Jesus No Real Collegio dos Estudos Geraes desta Corte, nos dias 24, e 25 de Setembro de 1754; e Oraçaõ funebre, que disse o M. R. Padre Mestre Estanislao Manso Da mesma Companhia de Jesus, lente de Prima que foy de Theologia no Real Collegio das Artes da Universidade de Coimbra, Consultor do Santo Officio, Examinador das Tres Ordens Militares, e actual Lente de Moral no mesmo Collegio dos estudos Geraes. Lisboa: Na Officina de Joaquim Tavares de Almeida, 1755.

${ }^{26}$ RELAÇAM das festas que a Religiam da Companhia de Iesv fez em a Cidade de Lisboa, na Beatificaçam do Beato P. Francisco de Xauier, Segundo Padroeiro da mesma Companhia, \& Primeiro Apostolo dos Reynos de Iapão, em Dezẽbro de 1620. Recolhidas polo Padre Diogo Marques Salgueiro do habito de Santiago, Prior que foy na villa de Mertola, oje Confessor, \& Capellaõ no Real Mosteiro de Santos o nouo. Lisboa: Ioão Rodriguez, 1621.

${ }^{27}$ RELAÇÕES das sumptuosas festas, com que a Companhia de Jesus Da Provincia de Portugal celebrou a Canonizaçaõ de S. Ignacio de Loyola, e S. Francisco Xavier Nas Casas, e Collegios de Lisboa, Coimbra, Evora, Braga, Bragança, Villaviçosa, Porto, Portalegre, e nas Ilhas da Madeira, e Terceira. Lisboa: [s.n.], 1622.

${ }^{28}$ Relaçaõ breve das exequias do Reverendissimo Padre Antonio Vieira, que o Conde da Ericeira Fez celebrar na Igreja de S. Roque da Casa Professa da Companhia de Jesus Em 17. de Dezembro de 1697. In: ORAÇAÕ funebre nas exequias do Reverendissimo Padre Antonio Vieira Da Companhia de JESU, Prégador dos Reys D. Joaõ IV. D. Affonso VI. e D. Pedro II. Que na Igreja de S. Roque fez celebrar o Conde da Ericeira D. Francisco Xavier de Menezes Em 17. de Dezembro de 1697. Disse-a o P. D. Manoel Caetano de Sousa, Clerigo Regular, hoje do Conselho de S. Magestade, Pro-Commissario Geral Apostolico da Bulla da Santa Cruzada, e Censor da Academia Real; Mandada imprimir por ordem de S. Magestade. Vay no fim huma Relaçaõ daquelle Acto. Lisboa Occidental: Na Officina de Joseph Antonio da Sylva, Impressor da Academia Real, 1730.

${ }^{29}$ RELAÇAÕ das festas do Collegio do Espirito Santo da Cidade de Evora na beatificaçaõ do Veneravel P. Joaõ Francisco Regis da Companhia de \{IHS \}. Évora: Na Officina da Universidade, 1717.

${ }^{30}$ OLIVEIRA, João de. Relaçaõ das festas com que o Collegio de Saõ Paulo da Companhia de Jesus da Cidade de Braga, celebrou em hũ Solemne Triduo a Canonizaçã̃ dos seus gloriosos Santos Luiz Gonzaga, e Estanislao Kostka em Julho de 1727. sendo Reitor o M.R.P.M. Bento Viegas, escrita por Joaõ de Oliveira natural de Braga. Lisboa Occidental: Na Patriarcal Officina da Musica, 1728; RELAÇAM, das festas Da Casa Professa de S. Roque da Cidade de Lisboa Occidental. Nas canonizaçoens dos dous Illustres Santos Luis Gonzaga, e Stanislao Koska, da Companhia de Jesus. Lisboa Occidental: Na Officina de Manoel Fernandes da Costa, Impressor do Santo Officio, 1728; RELAÇAÕ summaria das festas, que em a canonizaçaõ dos gloriosos santos Luiz Gonzaga, e Stanislao Kostka, celebraraõ Os Padres da Companhia de Jesus do Collegio de Santarem, supposto o decreto da canonização de Santo Stanislao Kostka, passado pela Santidade de Clemente XI. e tambem o applauso, que por entaõ se lhe consagrou. Lisboa Occidental: Na Officina de Joseph Antonio da Sylva, 1728; RELAÇAM do apparato triunfal, \& Procissaõ Solemne, comque os P.P. da Companhia de JESUS do Collegio de Evora applaudiraõ publicamente aos gloriozos S. Luiz Gonzaga, e Stanislao Kostka da mesma Companhia novamente Canonizados pelo Sanctissimo Padre Benedicto XIII. Agora Prezidente na Igreja de Deos. Évora: na Officina da Universidade, 1728; RELAÇAM das festas, Com q o Collegio, \& Universidade da Companhia de JESU da cidade de Evora Applaudio a Canonizaçaõ dos dous gloriozos santos, Luis Gonzaga, e Estanislao Kostka Da mesma Companhia Em Novembro de 1727. Évora: na Officina da Universidade, 1730. 
${ }^{31}$ EMBLEMAS, e poesias, Com que se adornou a Caza Professa do Bom Jesus de Goa, Quando nelle se celebraraõ as Exequias Do Illustris. e Excellentis. Senhor D. Luiz de Menezes Conde da Ericeira, Marquez do Louriçal, segunda vez Viso-Rey, e Capitão General do Estado da India. [S.1.]: [s.n.], [1745?].

${ }^{32}$ RELAÇAÕ summaria das festas, que em a canonizaçaõ dos gloriosos santos Luiz Gonzaga, e Stanislao Kostka, celebraraõ Os Padres da Companhia de Jesus do Collegio de Santarem... op. cit., p. 11.

${ }^{33}$ CAMPOS, Manoel de. Relaçam do solenne recebimento que se fez em Lisboa ás santas reliquias q ${ }^{\sim}$. se leuáram à igreja de S. Roque... op. cit., p. 65v-66r.

${ }^{34}$ Idem, p. 58r.

${ }^{35}$ Relaçaõ breve das exequias do Reverendissimo Padre Antonio Vieira, que o Conde da Ericeira Fez celebrar na Igreja de S. Roque da Casa Professa da Companhia de Jesus Em 17. de Dezembro de 1697... op. cit., p. 60.

${ }^{36}$ DESCRIPÇAÕ das exequias, que a' fidelissima rainha de Portugal a senhora D. Maria Anna de Austria... op. cit., p. 28.

${ }^{37}$ RELAÇÕES das sumptuosas festas, com que a Companhia de Jesus Da Provincia de Portugal celebrou a Canonizaçaõ de S. Ignacio de Loyola, e S. Francisco Xavier... op. cit., p. 41r.

${ }^{38}$ RELAÇÕES das sumptuosas festas, com que a Companhia de Jesus Da Provincia de Portugal celebrou a Canonizaçaõ de S. Ignacio de Loyola, e S. Francisco Xavier... op. cit., p. 56v.

${ }^{39}$ Relaçaõ breve das exequias do Reverendissimo Padre Antonio Vieira, que o Conde da Ericeira Fez celebrar na Igreja de S. Roque da Casa Professa da Companhia de Jesus Em 17. de Dezembro de 1697... op. cit., p. 58-9.

${ }^{40}$ RELAÇÕES das sumptuosas festas, com que a Companhia de Jesus Da Provincia de Portugal celebrou a

Canonizaçaõ de S. Ignacio de Loyola, e S. Francisco Xavier... op. cit., p. 20v.

${ }^{41}$ Idem, p. $123 \mathrm{v}$.

42 DESCRIPÇAÕ das exequias, que a' fidelissima rainha de Portugal a senhora D. Maria Anna de Austria... op. cit., p. 26.

${ }^{43}$ Isso ocorreu, em Évora, em ocasião das festas de beatificação do Pe. João Francisco Régis e de canonização dos jesuítas Luiz Gonzaga e Estanislau Kostka e, em Lisboa, nas exéquias de D. Maria Ana de Áustria.

${ }^{44}$ Vd. Relaçaõ breve das exequias do Reverendissimo Padre Antonio Vieira, que o Conde da Ericeira Fez

celebrar na Igreja de S. Roque da Casa Professa da Companhia de Jesus Em 17. de Dezembro de 1697... op. cit., p. 58-9.

${ }^{45}$ RELAÇÕES das sumptuosas festas, com que a Companhia de Jesus Da Provincia de Portugal celebrou a Canonizaçaõ de S. Ignacio de Loyola, e S. Francisco Xavier... op. cit., p. 127r.

${ }^{46}$ DESCRIPÇAÕ das exequias, que a' fidelissima rainha de Portugal a senhora D. Maria Anna de Austria... op. cit., p. 20, 35.

${ }^{47}$ Fotografias desses emblemas feitas por Ricardo Hernán Medrano (julho de 2008) podem ser vistas em: MARTINS, Renata Maria de Almeida. Tintas da Terra, Tintas do Reino: arquitetura e arte nas Missões Jesuíticas do Grão-Pará (1653-1759). Tese de Doutorado sob orientação do Prof. Luciano Migliaccio. São Paulo: Faculdade de Arquitetura e Urbanismo, Universidade de São Paulo, 2009, 2 v., (v. I, p. 451-2, Figuras 133-6).

${ }^{48}$ Fotografias desses emblemas feitas por Ricardo Hernán Medrano (julho de 2008) podem ser vistas em: Idem, v. 1, p. 446-7, Figuras 120, 122, 124, 126.

${ }^{49}$ Idem, v. 1, p. 447.

${ }^{50}$ Variante da sentença "Aut repellit aut frangitur" - ou repele ou se quebra.

${ }^{51}$ PASTOUREAU, Michel. Bestiari del Medioevo. Torino: Giulio Einaudi editore, 2011, (p. 277).

\section{Referências}

http://www.thelatinlibrary.com/juvenal/10.shtml. Acesso em 09/12/2018.

AMARAL JÚNIOR, Rubem. Portuguese Emblematics: an overview. Revista Lumen et Virtus, v. 2, n. 4, p. 134-48, mai. 2011. BIBLIOTECA NACIONAL. Anais da Biblioteca Nacional, v. 83, 1963. Brasiliana da Coleção Barbosa Machado. Catálogo organizado pela bibliotecária Rosemarie Horch. Divisão de Publicações e Divulgação, 1967, n. 107.

BIBLIOTHECA latino poetica, varia complectens opuscula latinorum poetarum e societate jesu qui in lusitana Peovincia florent... Nunc primùm collecta, digestaque opera ac studio $\mathrm{P}$. M. Didaci Camarae, 2 vols. Ulyssipone: ex pracio Michaelis Manescal da Costa, 1754. 
CAMPOS, Manoel de. Relaçam do solenne recebimento que se fez em Lisboa ás santas reliquias q̃ . se leuáram à igreja de $S$. Roque da companhia de IESV aos. 25. de Ianeiro de 1588. Pello Licenciado Manoel de Campos. Lisboa: per Antonio Ribeiro, 1588. DESCRIPÇAÕ das exequias, que a' fidelissima rainha de Portugal a senhora D. Maria Anna de Austria, De feliz, e saúdoza Memoria, celebraraõ os PP. Procuradores Das Missoẽs do Oriente da Companhia de Jesus No Real Collegio dos Estudos Geraes desta Corte, nos dias 24, e 25 de Setembro de 1754; e Oraçaõ funebre, que disse o M. R. Padre Mestre Estanislao Manso Da mesma Companhia de Jesus, lente de Prima que foy de Theologia no Real Collegio das Artes da Universidade de Coimbra, Consultor do Santo Officio, Examinador das Tres Ordens Militares, e actual Lente de Moral no mesmo Collegio dos estudos Geraes. Lisboa: Na Officina de Joaquim Tavares de Almeida, 1755.

DIMLER, G. Richard; DALY, Peter Maurice (eds.). The Jesuit Series (Corpus Librorum Emblematum). Toronto, Buffalo: University of Toronto Press, 1997-2007, 5 vols.

EMBLEMAS, e poesias, Com que se adornou a Caza Professa do Bom Jesus de Goa, Quando nelle se celebraraõ as Exequias Do Illustris. e Excellentis. Senhor D. Luiz de Menezes Conde da Ericeira, Marquez do Louriçal, segunda vez Viso-Rey, e Capitão General do Estado da India. [S.1.]: [s.n.], [1745?].

GIARD, Luce. Le devoir d'intelligence ou l'insertion des jésuites dans le monde du savoir.

In:___ (dir.). Les jésuites a la Renaissance. Système éducatif et production du savoir. Paris: Presses Universitaires de France, 1995, p. XI-LXXIX.

INSOLERA, Lydia Salviucci. L'Imago Primi Saeculi (1640) e il significato dell'immagine allegorica nella Compagnia di Gesù. Genesi e fortuna del libro. Roma: Editrice Pontificia Università Gregoriana, 2004.

LEITE, Serafim. História da Companhia de Jesus no Brasil, 10 vols. Porto, Rio de Janeiro: Tipografia Pôrto Médico, Imprensa Nacional, 1938-1950.

MACHADO, Diogo Barbosa. Bibliotheca Lusitana, Historica, Critica, e Chronologica, na qual se comprehende a noticia dos Authores Portuguezes, e das Obras, que compozerã̃ desde o tempo da promulgaçaõ da Ley da Graça até o tempo presente; por Diogo Barbosa Machado, Ulyssiponense, Abbade Reservatario da Paroquial Igreja de Santo Adrião de Sever, e Academico do Numero da Academia Real. Lisboa: Na Officina Patriarcal de Francisco Luiz Ameno, 1759, t. I.

MANNING, Patricia W. La emblemática jesuítica en El Criticón. eHumanista, vol. 9, p. 21840, 2007.

MARTINS, Renata Maria de Almeida. Tintas da Terra, Tintas do Reino: arquitetura e arte nas Missões Jesuíticas do Grão-Pará (1653-1759). Tese de Doutorado sob orientação do Prof. Luciano Migliaccio. São Paulo: Faculdade de Arquitetura e Urbanismo, Universidade de São Paulo, 2009, v. 1.

Un emblema volante...! A adaptação da tradição emblemática nas missões

jesuíticas da América Latina (séculos XVI-XVIII). In: CHAMBOULEYRON, Rafael;

ARENZ, Karl-Heinz (orgs.). Anais do IV Encontro Internacional de História Colonial.

Encontros com a história colonial. Belém: Editora Açaí, 2014, v. 1.

MASSIMI, Marina (org.). A novela História do predestinado peregrino e de seu irmão

Precito (1682). Compêndio dos saberes antropológicos e psicológicos dos jesuítas no Brasil colonial. São Paulo: Edições Loyola, 2012.

MURRIN, Michael. Renaissance allegory from Petrarch to Spencer. In: COPELAND, Rita; STRUCK, Peter T. (eds.). The Cambridge Companion to allegory. Cambridge: Cambridge University Press, 2010, p. 185-200.

OLIVEIRA, João de. Relaçaõ das festas com que o Collegio de Saõ Paulo da Companhia de Jesus da Cidade de Braga, celebrou em hũ Solemne Triduo a Canonizaçaõ dos seus 
gloriosos Santos Luiz Gonzaga, e Estanislao Kostka em Julho de 1727. sendo Reitor o M.R.P.M. Bento Viegas, escrita por Joaõ de Oliveira natural de Braga. Lisboa

Occidental: Na Patriarcal Officina da Musica, 1728.

PASTOUREAU, Michel. Bestiari del Medioevo. Torino: Giulio Einaudi editore, 2011. RAYBOULD, Robin. An introduction to the symbolic literature of the renaissance. Victoria: Trafford Publishing, 2005

RELAÇAM das festas, Com q o Collegio, \& Universidade da Companhia de JESU da cidade de Evora Applaudio a Canonizaçaõ dos dous gloriozos santos, Luis Gonzaga, e Estanislao Kostka Da mesma Companhia Em Novembro de 1727. Évora: na Officina da Universidade, 1730.

RELAÇAM, das festas Da Casa Professa de S. Roque da Cidade de Lisboa Occidental. Nas canonizaçoens dos dous Illustres Santos Luis Gonzaga, e Stanislao Koska, da Companhia de Jesus. Lisboa Occidental: Na Officina de Manoel Fernandes da Costa, Impressor do Santo Officio, 1728.

RELAÇAM das festas que a Religiam da Companhia de Iesv fez em a Cidade de Lisboa, na Beatificaçam do Beato P. Francisco de Xauier, Segundo Padroeiro da mesma Companhia, \& Primeiro Apostolo dos Reynos de Iapão, em Dezẽbro de 1620. Recolhidas polo Padre Diogo Marques Salgueiro do habito de Santiago, Prior que foy na villa de Mertola, oje Confessor, \& Capellaõ no Real Mosteiro de Santos o nouo. Lisboa: Ioão Rodriguez, 1621.

RELAÇAM do apparato triunfal, \& Procissaõ Solemne, comque os P.P. da Companhia de JESUS do Collegio de Evora applaudiraõ publicamente aos gloriozos S. Luiz Gonzaga, e Stanislao Kostka da mesma Companhia novamente Canonizados pelo Sanctissimo Padre Benedicto XIII. Agora Prezidente na Igreja de Deos. Évora: na Officina da Universidade, 1728.

Relaçaõ breve das exequias do Reverendissimo Padre Antonio Vieira, que o Conde da Ericeira Fez celebrar na Igreja de S. Roque da Casa Professa da Companhia de Jesus Em 17. de Dezembro de 1697. In: ORAÇAÕ funebre nas exequias do Reverendissimo Padre Antonio Vieira Da Companhia de JESU, Prégador dos Reys D. Joaõ IV. D. Affonso VI. e D. Pedro II. Que na Igreja de S. Roque fez celebrar o Conde da Ericeira D. Francisco Xavier de Menezes Em 17. de Dezembro de 1697. Disse-a o P. D. Manoel Caetano de Sousa, Clerigo Regular, hoje do Conselho de S. Magestade, Pro-Commissario Geral Apostolico da Bulla da Santa Cruzada, e Censor da Academia Real; Mandada imprimir por ordem de S. Magestade. Vay no fim huma Relaçaõ daquelle Acto. Lisboa Occidental: Na Officina de Joseph Antonio da Sylva, Impressor da Academia Real, 1730.

RELAÇAÕ das festas do Collegio do Espirito Santo da Cidade de Evora na beatificaçaõ do Veneravel P. Joaõ Francisco Regis da Companhia de \{IHS \}. Évora: Na Officina da Universidade, 1717.

RELAÇAÕ summaria das festas, que em a canonizaçaõ dos gloriosos santos Luiz Gonzaga, e Stanislao Kostka, celebraraõ Os Padres da Companhia de Jesus do Collegio de Santarem, supposto o decreto da canonização de Santo Stanislao Kostka, passado pela Santidade de Clemente XI. e tambem o applauso, que por entaõ se lhe consagrou. Lisboa Occidental: Na Officina de Joseph Antonio da Sylva, 1728.

RELAÇÕES das sumptuosas festas, com que a Companhia de Jesus Da Provincia de Portugal celebrou a Canonizaçaõ de S. Ignacio de Loyola, e S. Francisco Xavier Nas Casas, e Collegios de Lisboa, Coimbra, Evora, Braga, Bragança, Villaviçosa, Porto, Portalegre, e nas Ilhas da Madeira, e Terceira. Lisboa: [s.n.], 1622.

RODRIGUES, Francisco. História da Companhia de Jesus na Assistência de Portugal, 7 vols. Pôrto: Apostolado da Imprensa, 1931-1950. 
TELES, Baltasar. Chronica da Companhia de Iesv, da provincia de Portugal. Segvnda parte, na qval se contem as vidas de algũs Religiosos mais assinalados, que na mesma Provincia entràram, nos annos em que viveo S. Ignacio de Loyola, nosso fvndador. Com o svmmario das vidas dos Serenissimos Reys Dom Ioàm Terceyro, \& Dom Henrique, Fundadores, \& insignes bemfeytores desta Provincia. Composta pelo P. M. Balthezar Telles, da mesma Companhia, natural da Cidade de Lisboa. Lisboa: por Paulo Craesbeeck, 1647. Disponível em: <https://digital.bbm.usp.br/handle/bbm/4690>. Acesso em: 24/07/2018, 16:11:05.

Chronica da Companhia de Iesv, na provincia de Portugal; e do qve fizeram, nas conquistas d'este Reyno, os Religiosos, que na mesma Provincia entràram, nos annos em que viveo S. Ignacio de Loyola, nosso Fundador. Pelo P. M. Balthazar Tellez da mesma Companhia, natural da cidade de Lisboa, \& nella Lente de Prima de Theologia. Primeira parte, na qval se contem os principios d'esta Provincia, No tempo, em que a fundou, \& governou o P. M. Simam Rodrigves, Com sua sancta vida, \& morte. Lisboa: por Paulo Craesbeeck, 1645. Disponível em: <https://digital.bbm.usp.br/handle/bbm/4678>. Acesso em: 24/07/2018, 16:09:38.

VASCONCELOS, Simão de. Chronica da Companhia de Jesv do estado do Brasil: e do qve obrarão sevs filhos nesta parte do Novo mvndo. Tomo primeiro: da entrada da Companhia de Jesv nas partes do Brasil. E dos fvndamentos que nellas lançârão, \& continuàrão seus religiosos em quanto alli trabalhou o padre Manoel da Nobrega, fundador, \& primeiro prouincial desta prouincia, com sua vida, \& morte digna de memoria: e algṽas Noticias antecedentes curiosas, \& necessarias das cousas daquelle estado. Lisboa: H. Valente de Oliuiera, impressor del Rey, N. S., 1663.

. Crônica da Companhia de Jesus. Petrópolis, Brasília: Vozes, Instituto

Nacional do Livro, 1977, v. 1. 